\title{
LIITPREDIKAADID LEKSIKONI-GRAMMATIKA KONTIINUUMIL: KONSTRUKTSIOONIDE PRODUKTIIVSUSEST VERBIGA MINEMA MOODUSTATUD LIITPREDIKAATIDE NÄITEL ${ }^{1}$
}

\author{
Kadri Muischnek \\ Tartu Ülikool \\ Heete Sahkai \\ Eesti Keele Instituut
}

Kokkuvõte. Artiklis kirjeldatakse korpusandmete põhjal rühma eesti keele liitpredikaatide produktiivsust ning arutletakse selle tegurite üle. Konstruktsioonide produktiivsust hinnatakse Harald Baayeni (2009) realiseerunud ja potentsiaalse produktiivsuse valemite, konstruktsioonide semantilise ühtsuse (Barðdal 2008) ja uudse meetodina ühendite kollokatsioonilise seose tugevuse põhjal. Uurimuse tulemusena leitakse, et ehkki vaadeldud liitpredikaatidel on mitu sarnast omadust, esindavad nad väga erinevaid produktiivsuse tüüpe ja astmeid: andmestikus leidub üksikuid kinnistunud ühendeid, mis ei ole siiski produktiivsuse seisukohast täiesti inertsed; suurem semantiliselt ühtne kinnistunud ühendite rühm, mis ilmutab mõningaid analoogilise laienemise märke; väga kitsastes semantilistes piirides produktiivne mall; ning kaks semantiliselt avatud, erineval määral produktiivset ja erinevat tüüpi malli. Produktiivsuse tegurina ilmneb üldisema sünonüümse või homonüümse malli olemasolu, mis tundub takistavat uue malli teket või laienemist. Üldisemalt leitakse, et liitpredikaadid pakuvad head ainestikku produktiivsuse ja selle tegurite uurimiseks ning mittemodulaarsete, kasutuspõhiste ja leksikoni-grammatika kontiinuumi eeldavate teooriate arendamiseks.

Märksõnad: eesti keel, liitpredikaadid, konstruktsioonid, produktiivsus, korpuspõhine uurimus, kollokatsioonitugevus, keeleteooria

\footnotetext{
${ }^{1}$ Artikli valmimist on toetanud Euroopa Regionaalarengu Fond Eesti Arvutiteaduse Tippkeskuse EXCS kaudu, sihtfinantseerimisteemad SF0050023s09 ja SF0180078s08 ning ETFi grant 7149.
} 


\section{Sissejuhatus}

Artiklis kirjeldatakse korpusandmete põhjal rühma eesti keele liitpredikaate ja liitpredikaadimalle ${ }^{2}$, mis koosnevad verbist minema ja ma-infinitiivist või allatiivis/illatiivis/translatiivis (tegevus)nimisõnast ning väljendavad tegevuse algust või tulevikulisust $^{3}$, nt Majandus läheb langusele/langusse, Vesi läheb keema, Öpik läheb kasutusele/kasutusse, Kino läheb sulgemisele, Neil läheb löömaks.

Vaadeldavaid konstruktsioone võib pidada liitpredikaatideks, sest neis esinev finiitverb ei ole iseseisvalt lause semantiline ja süntaktiline kese ning $m a$-infinitiiv või nimisõna ei ole tavapärane laiend, vaid osaleb subjektiselektsioonis ja võib tingida ka muid lauseliikmeid: nt lauses Koolides läheb kasutusse uus opik on alusfraas „uus õpik“ ja määrus „,koolides“ tingitud nimisõna „kasutus“ tähendusest. Vaadeldavad ühendid toimivad tervikuna predikaadina ning on teatud määral mittekompositsioonilise tähendusega (liitpredikaatide definitsioone vt Alsina jt 1997: 1; EKG II: 19, Metslang 1994: 160 ja 2004).

Artikli eesmärk on uurida liitpredikaate kui ainestikku, mis võimaldab arendada mittemodulaarseid, kasutuspõhiseid ja leksikoni-grammatika kontiinuumi eeldavaid keelekäsitlusi. On ju liitpredikaadid leidnud tihti käsitlemist just oma problemaatilisuse tõttu modulaarsete teooriate jaoks, kuivõrd nad on samaaegselt süntaktilised ja leksikaalsed üksused (vt nt

${ }^{2}$ Räägime neist edaspidi kokkuvõtlikult kui „liitpredikaatidest“ või „konstruktsioonidest“, pidades silmas nii konkreetseid püsiühendeid kui ka (osaliselt) skemaatilisi malle.

${ }^{3}$ Alguse- ja tulevikutähenduse seostest vt Metslang 1994: 606-609. Tegevuse alguse või tulevikulisuse väljendamise funktsionaalsesse nišši mahub väga palju erineva üldisusastmega ja erinevate semantiliste või pragmaatiliste nüanssidega konstruktsioone: vaadeldavate konstruktsioonide kõrval kuuluvad sinna nii üldisemad grammatilised ja leksikaalsed vahendid, nagu [hakkama+ma-infinitiiv] (verbi hakkama kui universaalse fraasiverbi kohta vt Metslang 1994: 607) ja verbid algama, alustama, teiselt poolt spetsiifilisemad konstruktsioonid, nagu [jääma/kukkuma/puhkema + ma-infinitiiv] või verbid puhkema, lahti minema, lahvatama. 
Ackerman ja Webelhuth 1998, Alsina jt 1997, Butt 2003, Müller 2002 ja Lüdeling 2001). Samuti on problemaatiline liitpredikaatide eristamine vabadest süntaktilistest ühenditest (kriteeriume selleks on välja pakkunud Helle Metslang 2002 ja 2004; püsiühendite piiritlemise raskustest vt Muischnek 2006), nad tunduvad paiknevat süntaksi ja leksikoni ning süntaksi ja morfoloogia vahelistel kontiinuumidel. Meie andmestik illustreerib veel üht kontiinuumi, millele liitpredikaadid paigutuvad: püsiühendite ja abiverbikonstruktsioonide ehk leksikaalsete ja grammatiliste liitpredikaatide kontiinuumi. See tähendab, et problemaatiline on ka liitpredikaatide klassifitseerimine (eesti keele liitpredikaatide klassifikatsioone vt EKG II: 18-22 ja Erelt 2003: 101-102). Seega peaksid liitpredikaadid olema sobiv ainestik uurimaks, millised on keelelise teadmise üksused, kui nad ei jagune „sõnadeks ja reegliteks“ ning ühendavad endas informatsiooni erinevatelt keeletasanditelt.

Täpsemalt püüame kirjeldada vaatlusaluste konstruktsioonide produktiivsust ning arutleda selle tegurite üle. Teiste sõnadega, me uurime, kuidas ja mil määral need konstruktsioonid võimaldavad moodustada uusi, mittekonventsionaalseid keeleväljendeid. Konstruktsioonide produktiivsus pakub antud kontekstis huvi seetõttu, et produktiivsuse kontiinuumi võib pidada leksikoni-grammatika kontiinuumi üheks oluliseks dimensiooniks ning osalist produktiivsust üheks keelelise teadmise kasutuspõhise iseloomu ilminguks. Konstruktsioonide produktiivsust on viimasel ajal käsitlenud või selle uurimise olulisust rõhutanud nt Barðdal 2008, Boas 2008, Bybee ja Eddington 2006, Goldberg 2006 ning Jackendoff 2008.

Konstruktsioonide produktiivsuse ja selle tüüpide ning tegurite uurimine võimaldab uurida ka, kuidas on keeleline teadmine struktureeritud, kuidas toimub uudsete keeleväljendite moodustamine ning kuidas skemaatilised konstruktsioonid tekivad ja laienevad. Artikli eesmärk ei ole muidugi neile küsimustele ammendavalt vastata, vaid pigem näidata, et liitpredikaadid on hea ainestik sedalaadi teemade uurimiseks.

Artikkel on üles ehitatud järgmiselt. Kõigepealt anname ülevaate andmestikust ja selle kogumisest ning konstruktsioonide produktiivsuse hindamiseks kasutatud meetoditest. Seejärel 
analüüsime ükshaaval vaatlusaluseid konstruktsioone ja lõpuks esitame järeldused ning kokkuvõtte.

\section{Andmestik}

Et uurida produktiivsuse tegureid, analüüsisime erineva produktiivsusega konstruktsioone, mis on samas mitmes mõttes sarnased (ehk mitu võimalikku produktiivsuse tegurit on kontrollitud): kõik vaadeldavad konstruktsioonid on sarnase aspektuaalse/temporaalse tähendusega ning koosnevad finiitverbist minema ja latiivses vormis tuumast ${ }^{4}$ (nimisõnast või $m a$-infini-

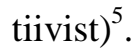

Materjal selle uurimuse jaoks pärineb Tasakaalus korpuse ${ }^{6}$ morfoloogiliselt märgendatud versioonist. See korpus sisaldab võrdses mahus ilukirjandus-, ajakirjandus- ja teadustekste, kokku 15 miljonit sõna. Korpusest leiti automaatselt kõik verbi minema ja translatiivis/allatiivis/illatiivis nimisõna või $m a$-infinitiivi paarid. Paarilised olid samast lausest ja nende vahel ei tohtinud olla rohkem kui kolm sõna.

Selliselt saadud sõnapaaride hulgas oli nii meid huvitavate liitpredikaatide esindajaid kui ka muu tähenduse, kuid sama struktuuriga keelendeid, mistõttu saadud loendid tuli käsitsi läbi kontrollida. Paaride kategoriseerimisel erinevateks konstruktsioonideks või erinevate konstruktsioonide esindajateks võtsime arvesse nii nende vormi kui ka tähendust, samuti väljendite sisuliseks tuumaks olevate sõnade semantilist sarnasust/erinevust. Tuleb siiski öelda, et andmestiku klassifitseerimine jäi mingil määral meelevaldseks, millele konstruktsioone kirjeldades ka tähelepanu juhime.

Kui korpusandmete põhjal ei olnud võimalik konstruktsiooni produktiivuse üle üheselt otsustada (näiteks ei olnud selge, kas

\footnotetext{
${ }^{4}$ EKG eeskujul nimetame liitpredikaatide mittefiniitset komponenti sisuliseks tuumaks.

${ }^{5}$ Andmestik ei hõlma kõiki sellele kirjeldusele vastavaid konstruktsioone.

${ }^{6}$ http://www.cl.ut.ee/korpused/grammatikakorpus/
} 
konstruktsioonis saab esineda mingi semantiline sõnaklass tervikuna või ainult üksikud selle esindajad), otsisime andmeid juurde ka internetist.

\section{Produktiivsuse mõõtmine}

Konstruktsioonide produktiivsuse hindamiseks kasutasime Harald Baayeni (2009) välja pakutud meetodit (morfoloogilise) produktiivsuse arvutamiseks, mis formaliseerib seisukohti, et produktiivseid kategooriaid iseloomustab suur hulk erinevaid vorme, millest igaühe sagedus tekstis on väike, samas kui mitteproduktiivsed kategooriad koosnevad suure tekstisagedusega vormidest. Baayen esitab kolm (morfoloogilise) produktiivsuse leidmise valemit:

1) realiseerunud produktiivsus, st tüübisagedus: kui palju erinevaid sõnu mingi tuletusliitega on moodustatud, st on mingis korpuses loendatud;

2) potentsiaalne produktiivsus iseloomustab konstruktsiooni laienemist (tuletusliite kasvavat kasutamist uute tuletiste moodustamiseks) ja selle leidmiseks jagatakse mingi tuletusliitega moodustatud ja korpuses ainult üks kord esinenud tuletiste arv kõigi selle tuletusliitega moodustatud sõnade arvuga (tekstisagedusega);

3) kolmandaks morfoloogilise produktiivsuse näitajaks on Baayenil laienemisproduktiivsus, mis mõõdab kiirust, millega kategooria laieneb, st levib uutesse kontekstidesse (näiteks tuletusliide levib uutele tüvedele). Laienemisproduktiivsus leitakse kõigi korpuses olevate ainukordsete üksuste ja uuritava kategooria ainukordsete üksuste suhtena.

Nendest valemitest kahte esimest saab kasutada ka süntaktilise produktiivsuse mõõtmisel, juhul, kui on teada mingi konstruktsiooni teksti- ja tüübisagedus. Kolmandat valemit kasutada ei saa, sest pole teada, mida peaks arvestama korpuse kõigi ainukordsete üksuste leidmisel - kas kõiki liitpredikaate selles korpuses? Konstruktsioonigrammatikast lähtudes ilmselt kõiki konstruktsioone selles korpuses (kui morfoloogilise produktiivsuse leidmisel arvestati leksikoniüksustega, siis konstruktsiooni- 
lise produktiivsuse leidmisel peaks arvestama konstruktsioonidega ehk „konstruktikoniüksustega“ (Fillmore 2006 ja 2008)); aga see pole, vähemalt hetkel, praktikas teostatav.

Uudse meetodina võtsime uuritavate liitpredikaatide produktiivsuse määramisel kasutusele arvutilingvistikas tavaliselt kollokatsioonilise seose tugevuse leidmiseks kasutatavad sõnadevahelise seose tugevuse mõõtmise statistikuid (association measures). Need statistikud ${ }^{7}$ (nt t-test jpt) omistavad korpusest leitud sõnapaaridele või -mitmikutele sõnadevahelise seose tugevuse väärtused, arvestades sõnaühendi sagedust korpuses, sõnaühendit moodustavate sõnade eraldiesinemise sagedusi ja korpuse suurust. Tüüpiliselt on seose tugevuse arvuline väärtus suur (st on suure tõenäosusega püsiühend) sellise sõnaühendi puhul, mis ise on sage ja mille üks (ideaaljuhul mõlemad, aga seda esineb harva) komponent esineb väljaspool ühendit harva, nt väljendverb aru saama.

Eeldame, et produktiivset süntaktilist moodustusmalli iseloomustab see, et mall üldistusena on korpuses sage, tema esindajad konkreetsete sõnaühenditena aga pigem mitte. Seetõttu oletame, et need mallid, mille esindajad saavad kõrged seose tugevuse väärtused, koosnevad pigem püsiühendilaadsetest sõnaühenditest ja on mallina väiksema produktiivsusega ning need mallid, mida esindavate sõnaühendite seose tugevuse arvulised väärtused on pigem madalamad, on mallina produktiivsemad.

Uuritavate liitpredikaatide distributsioon sõnadevahelise seose tugevuse väärtuste järgi ning nende realiseerunud ja potentsiaalse produktiivsuse näitajad, samuti tekstisagedus ja ainult üks kord esinevate ühendite arv on esitatud iga konstruktsiooni analüüsi juures. Ühe produktiivsuse näitajana vaatleme ka konstruktsioonide semantilist ühtsust ehk seda, kas neis esinevad sõnad on sarnase tähendusega. Väiksema tüübisagedusega mallide puhul on semantiline ühtsus eeldus üldistuse tekkimiseks üle konkreetsete väljendite ja seega üldse skemaatilise malli tekkeks; suurema tüübisagedusega mallide puhul aga eeldab suurem produktiivsus väiksemat semantilist ühtsust ehk semantilist avatust, et mallil oleks laienemisruumi (Barðdal 2008: 34-44).

${ }^{7}$ Nende kohta vt täpsemalt Uiboaed (2010). 


\section{Konstruktsioonid}

\subsection{Aktiivsed intransitiivsed konstruktsioonid: tülli/kaklema minema, keema/liikuma minema, langusse/käibele/lendu minema jt}

Esiteks vaatleme kahte rühma ühendeid, millest ühe tuumaks on allatiivne või illatiivne (tegevus)nimisõna ja teisel $m a$-infinitiiv. Väljendite ühiseks omaduseks on aktiivne intransitiivne tähendus. Nende koosvaatlemist õigustab ka see, et $m a$-infinitiiv ning nimisõna allatiivi- ja illatiivivormid tunduvad neis moodustavat teatud määral ühe substitutsiooniklassi (Rätsepa (1978) mõistes). Potentsiaalselt väljendite taga olevate mallide produktiivsuse ja ühendite kollokatsioonitugevuse näitajad on esitatud tabelites 1, 2 ja 3; viimastes on esitatud ka näited.

\section{Tabel 1}

\begin{tabular}{|l|l|l|}
\hline näitajad & $\begin{array}{l}\text { minema } \\
\text { +allatiiv/illatiiv }\end{array}$ & $\begin{array}{l}\text { minema } \\
\text { +ma-infinitiiv }\end{array}$ \\
\hline $\begin{array}{l}\text { realiseerunud } \\
\text { produktiivsus }\end{array}$ & 27 & 27 \\
\hline $\begin{array}{l}\text { ainukordsed } \\
\text { ühendid }\end{array}$ & $13(48 \%)$ & $7(26 \%)$ \\
\hline tekstisagedus & 174 & 229 \\
\hline $\begin{array}{l}\text { potentsiaalne } \\
\text { produktiivsus }\end{array}$ & $0,07(13 / 174)$ & $0,03(7 / 229)$ \\
\hline
\end{tabular}

Tabel 1 esitab võrdlevalt kahe potentsiaalse aktiivse algusemalli - [minema+illatiiv/allatiiv] ja [minema+ma-infinitiiv] produktiivsusnäitajad. Keelendite tüübisagedus on võrdne, kuid tekstisagedus on $m a$-infinitiiviga konstruktsioonil suurem. Ligi pool allatiivi/illatiiviga moodustatud ühenditest on ainukordsed ja ka selle konstruktsiooni potentsiaalne produktiivsus on umbes kaks korda suurem kui $m a$-infinitiiviga konstruktsioonil.

Tabelid 2 ja 3 esitavad konstruktsioonide jaotumise t-testi põhjal kõigi korpusest leitud vastava vormiga ühendite pingereas; tabelite viimases veerus on võrdluseks esitatud samakujuliste püsiühendite jaotumine samas materjalis. Täpsemalt: 
kõik korpusest leitud minema ja illatiivi/allatiivi või $m a$-infinitiivi paarid, nende tähendust või kasutust arvestamata, järjestatakse t-testi väärtuse alusel. Selliselt saadud nimekirja eesotsas peaksid olema püsiühendid. Uurides, kuidas meid huvitavate konstruktsioonide esindajad selles nimekirjas paiknevad, saame oletatavasti teha järeldusi liitpredikaadimalli püsiühendilisuse vs. produktiivsuse kohta. Hõlbustamaks erinevate liitpredikaatide võrdlemist, oleme kõik sõnapaaride loendid jaotanud kümnesse astakusse ja esitame liitpredikaatide kumulatiivse protsendi nendes kümnendikes.

\section{Tabel 2}

\begin{tabular}{|l|l|l|l|}
\hline \multicolumn{2}{|l|}{$\begin{array}{l}\text { aktiivne intransitiivne minema } \\
\text { +allatiiv/illatiiv }\end{array}$} & $\begin{array}{l}\text { püsiühendid } \\
\text { kujul minema } \\
\text { +allatiiv/illatiiv }\end{array}$ \\
\hline astak & kumul. \% & näiteid & kumul. \% \\
\hline 1 & 22 & $\begin{array}{l}\text { tülli, riidu, võitlusse, käibesse, } \\
\text { lendu, ringlusse minema }\end{array}$ & 62 \\
\hline 2 & 37 & $\begin{array}{l}\text { paanikasse, tõusule, } \\
\text { ringlusesse, jooksu minema } \\
\text { käibele, langusele minema }\end{array}$ & 71 \\
\hline 3 & 44 & $\begin{array}{l}\text { külglennule minema } \\
\text { vabalangusse, vankvele, } \\
\text { vasakpöördesse minema }\end{array}$ & 71 \\
\hline 4 & 48 & $\begin{array}{l}\text { hävingusse minema } \\
\text { kokkupõrkele, ründamisele, }, \\
\text { viskele, teaduskäibesse } \\
\text { minema }\end{array}$ & 76 \\
\hline 5 & 59 & $\begin{array}{l}\text { pealetungile, otsingule } \\
\text { minema }\end{array}$ & 76 \\
\hline 7 & 81 & $\begin{array}{l}\text { oide minema, kasvatamisele } \\
\text { minema }\end{array}$ & 100 \\
\hline 8 & 85 & $\begin{array}{l}\text { kasutamisele minema, tööle } \\
\text { minema }\end{array}$ & 100 \\
\hline 10 & 100 & & 75 \\
\hline
\end{tabular}


Tabel 3

\begin{tabular}{|l|l|l|l|}
\hline \multicolumn{2}{|l|}{$\begin{array}{l}\text { aktiivne inhoatiivne minema } \\
+ \text { ma-infinitiiv }\end{array}$} & $\begin{array}{l}\text { püsiühendid } \\
\text { kujul minema } \\
\text { +ma-infinitiiv }\end{array}$ \\
\hline astak & kumul. \% & näiteid & kumul. \% \\
\hline 1 & 22 & $\begin{array}{l}\text { põlema, käima, keema, kasvama, } \\
\text { kaklema, vaidlema minema }\end{array}$ & 86 \\
\hline 2 & 44 & $\begin{array}{l}\text { mädanema, idanema, haisema, } \\
\text { särama, veerema, kasuma } \\
\text { minema }\end{array}$ & 93 \\
\hline 3 & 67 & $\begin{array}{l}\text { kõrbema, kiskuma, lehkama, } \\
\text { käärima, hallitama, hauduma } \\
\text { minema }\end{array}$ & 93 \\
\hline 4 & 67 & & 100 \\
\hline 5 & 70 & riidlema minema & 100 \\
\hline 6 & 81 & $\begin{array}{l}\text { haljendama, lonkama, lókendama } \\
\text { minema }\end{array}$ & 100 \\
\hline 7 & 89 & tiirlema, läikima minema & 100 \\
\hline 8 & 93 & pöörlema minema & 100 \\
\hline 9 & 100 & venima, liikuma minema & 100 \\
\hline 10 & 100 & & 100 \\
\hline
\end{tabular}

Ka tabelite 2 ja 3 põhjal võib väita, et $m a$-infinitiiviga moodustatud liitpredikaadid on pisut vähem produktiivsed kui allatiivi/illatiiviga moodustatud mall, sest $m a$-infinitiiviga väljendid on pisut enam „kuhjunud“ kõigi korpustest leitud minema ja ma-infinitiivi paaride t-testi põhjal järjestatud nimekirja esimesse poolde: kui oleme läbi vaadanud poole korpusest ekstraheeritud ühendite nimekirjast, oleme näinud $70 \%$ selle malli järgi moodustatud aktiivsetest inhoatiivsetest liitpredikaatidest; allatiivi/illatiiviga inhoatiivsete liitpredikaatide jaoks on see protsent 59, mida võib pidada tähenduslikuks erinevuseks. Võrdlusaluseks olevatest püsiühenditest paigutuvad siiski mõlema malli esindajad allapoole, millest võib järeldada, et väljendite näol ei ole tegemist ainult püsiühenditega. Et selgitada, mis on ilmnenud produktiivsusnäitajate ja nende erinevuse taga, 
analüüsisime väljendeid nende sisuliseks tuumaks olevate sõnade tähenduse seisukohast. Selle alusel võib väljendid jagada väiksemateks rühmadeks, mida vaatleme järgnevates alajaotustes.

\subsubsection{Konflikti väljendava tuumaga ühendid: tülli/kaklema minema jt}

Kõige selgepiirilisema rühma moodustavad ühendid, mille sisuliseks tuumaks on konflikti väljendav sõna. Neid leidub nii mainfinitiivi kui ka nimisõnaga ühendite hulgas, kuid need kaks on täiesti erineva produktiivsusega. Nimisõnalise tuumaga konfliktiväljendeid esindab korpuses kaks püsiühendit (tülli, riidu minema) ning miski ei viita sellele, et need võiksid esindada produktiivset malli. $m a$-infinitiiviga konfliktiväljendeid esindab korpuses küll ainult kolm ühendit (kaklema, kiskuma, vaidlema minema), millest väljendeid kaklema/vaidlema minema võib ka püsiühenditeks lugeda, kuid interneti-otsing näitab, et selle kitsa tähendusrühma piires on mall täiesti produktiivne. Sellise malli eksisteerimist eesti keele üldise alguskonstruktsiooni [hakkama $+m a$-infinitiiv] kõrval võib motiveerida asjaolu, et see tundub konstrueerivat konflikti mitteintentsionaalsena ning on seega kitsama tähendusega kui hakkama-mall, mis on intentsionaalsuse suhtes neutraalne (vrd Poisid kavatsevad õues kaklema hakata/?minna).

\subsubsection{Seisundit, protsessi ja liikumist väljendava tuumaga ühendid: keema/liikuma minema jt}

Ülejäänud $m a$-infinitiiviga ühendites esinevatest verbidest moodustavad suurima ja suhteliselt ühtse rühma füüsilist seisundit ja protsessi väljendavad verbid (16 sõna, nt keema, põlema). Sellise tuumaga ühendid on peamiselt kinnistunud väljendid ning kuigi nende hulgas on ka üksikuid mittekonventsionaalseid ühendeid (lainetama, venima minema), ei esinda nad produktiivset malli nagu $m a$-infinitiiviga konfliktiväljendid (nagu näitab interneti-otsing erinevate seisundi- ja protsessiverbidega). Põh- 
jus, miks väljendite semantilisest ühtsusest hoolimata ei ole nende põhjal tekkinud produktiivset malli ${ }^{8}$, võib olla selles, et väljendid ei eristu tähenduslikult üldisest hakkama-mallist (vrd Vesi läks keema hakkas keema), kuigi osal neist on teatud määral leksikaliseerunud tähendus (vrd kasvama minema ja kasvama hakkama). Samuti võib produktiivse malli tekkimist blokeerida homonüümne otstarbemääruse mall (nt sööma mine$m a)$, mis takistab malli laienemist agentiivsetesse kontekstidesse.

Tundub siiski, et teatud laiendusi on need väljendid andnud: ülejäänud $m a$-infinitiiviga ühendid andmestikus sisaldavad valdavalt liikumist väljendavaid verbe (6 juhtu) ning konstrueerivad liikumist ,,seisundi- või protsessitaolisena“" ${ }^{\text {, }}$, mis viitab sellele, et liikumisverbiga ühendid võivad olla moodustatud eelmise rühma analoogial. See on ka mõnevõrra innovatiivsem rühm, kuid mall ei ole ka selle tähenduse piires produktiivne nagu $m a$-infinitiiviga konfliktimall.

Kokkuvõttes võib ülejäänud $m a$-infinitiiviga väljendite kohta öelda, et tegu on valdavalt kinnistunud väljendite küllalt suure ja ühtse rühmaga, mille analoogial moodustatakse ka üksikuid uusi väljendeid.

\subsubsection{Varia: langusse/käibele/lendu minema jt}

Ülejäänud nimisõnalise tuumaga ühendid andmestikus ei moodusta omaette semantiliselt ühtset rühma ei väljendite endi ega neis esinevate sõnade tasandil: nad piirnevad ühelt poolt seisundimuutuseväljenditega (nt paanikasse minema) ja teiselt poolt otstarbemääruse konstruktsiooniga (nt võitlusse minema). Mõned neist on tähenduslikult seotud eelkäsitletud ma-infi-

\footnotetext{
${ }^{8}$ Ehkki eeldused selleks on olemas: väljendid moodustavad semantiliselt ühtse rühma ning sama semantilise välja sees on ka palju laienemisruumi, nt protsessiverbid, nagu paisuma, sulama, seisundiverbid nagu valutama, vihkama, paistma, vilkuma jne.

${ }^{9}$ See ilmneb sellest, et nad on mitteagentiivsed, eelistavad mitteteelisi verbe (nt tiirlema, keerlema) ja ei kombineeru vabalt siht- ja lähtekohta väljendavate määrustega, vrd Rong hakkas/?läks Tallinnast Tartu poole veerema/liikuma.
} 
nitiiviühenditega (vrd nt tööle minema 'käivituma' ja käima minema), kuid üldiselt moodustavad neis esinevad sõnad heterogeense rühma. Mitmed neist väljenditest on püsiühendid (nt käibele, langusele, tõusule minema), kuid on ka selgelt mittekonventsionaalseid ühendeid (nt vasakpöördesse minema). Viimaste aluseks ei ole ilmselt siiski skemaatiline mall ning eeldusi ei tundu olevat ka sellise malli tekkeks, sest väljendid ei ole semantiliselt ühtsed ega eristu sageli üldisest algusemallist (vrd nt Majandus läks langusse $\sim$ hakkas langema). Samuti on nad homonüümsed otstarbemääruse malliga (vrd minema puhkusele, matkale, tööotsingutele, valimistele), mis võib samuti takistada alguskonstruktsiooni teket ${ }^{10}$.

Nagu näha ka produktiivsusnäitajatest, ei ole kinnistunud ühendid siiski produktiivsuse seisukohast sugugi inertsed. Esiteks on iga kinnistunud üksus minimaalselt produktiivne selles mõttes, et pakub alust analoogilisteks laiendusteks (vrd Barðdal 2008: 43-44); meie andmestikus võib sellise produktiivsuse ilminguks pidada sünonüümide ja antonüümide seeriaid, nagu tülli/riidu minema (vrd ka raksu, pahuksisse, konflikti minema), tõusule/langusele minema; vahelduda võib ka finiitverb, nt tõusule minema/pöörama. Ehk liitpredikaatide kohta kehtib sama, mida Krikmann (2004: 107) on kirjutanud üldisemalt fraseoloogilise tüpoloogia kohta: „süntaktiline mall ise on üsna kindlapiiriliselt ette antud, kuid vabadused selle malli ühe või teise positsiooni leksikaalseks täitmiseks on hästi suured“". Sellega on seotud veel üks „püsiühendite produktiivsuse“ ilming, nimelt nende esinemine kausatiivsuse ja aspektiparadigmadena (nt langusse minema/viima - languses olema/hoidma - langusest välja tulema/välja tooma) - ühe väljendi teke teeb võimalikuks ka teised paradigmaliikmed, mis ise ei ole kinnistunud väljendid.

\footnotetext{
${ }^{10}$ Teiselt poolt on otstarbemääruse mall ise potentsiaalne tulevikumalli allikas, nagu näitab nt inglise keele to be going to-tulevik ja ka mõned näited meie andmestikus, samuti järgmisena kirjeldatav konstruktsioon.
} 


\subsection{Passiivne konstruktsioon: kasutusse/kasutusele minema, lammutamisele minema jt}

Selles ja järgmises alajaotuses vaatleme kahte erineval määral produktiivset malli. Nende produktiivsuse näitajad on esitatud tabelis 4 . Võrreldes tabelit 4 tabeliga 1 näeme, et mõlema malli nii realiseerunud kui ka potentsiaalne produktiivsus on suuremad kui aktiivsetel $m a$-infinitiiviga või allatiivi/illatiiviga moodustatud liitpredikaatidel.

\section{Tabel 4}

\begin{tabular}{|l|l|l|}
\hline näitajad & $\begin{array}{l}\text { passiivne minema } \\
\text { +allatiiv/illatiiv }\end{array}$ & $\begin{array}{l}\text { minema } \\
\text { +translatiiv }\end{array}$ \\
\hline $\begin{array}{l}\text { realiseerunud } \\
\text { produktiivsus }\end{array}$ & 78 & 120 \\
\hline $\begin{array}{l}\text { ainukordsed } \\
\text { ühendid }\end{array}$ & $44=56 \%$ & $83=68 \%$ \\
\hline tekstisagedus & 184 & 198 \\
\hline $\begin{array}{l}\text { potentsiaalne } \\
\text { produktiivsus }\end{array}$ & 0,2 & 0,41 \\
\hline
\end{tabular}

Vaatleme esiteks lähemalt passiivse tähendusega malli, mille sisuliseks tuumaks on allatiivne või illatiivne tegevusnimisõna. Tabelist 5 näeme, et malli esindajad paigutuvad t-testi põhjal järjestatud „püsiühendilisuse“ pingereas püsiühenditest allapoole.

Semantiliselt on mall suhteliselt avatud, mis viitab samuti produktiivsusele: selles esinevad kausatiivsete seisundimuutusverbide ja manipuleerimisverbide (nt remonti, hävitamisele,sorteerimisele), mentaalse tegevuse verbide (nt menetlusse, arutamisele, uurimisele), omandimuutusverbide (nt mü̈̈gile/mü̈̈ki, jagamisele, erastamisele), valmistamisverbide (nt tootmi(se)sse, teostamisele) nominalisatsioonid. Mallil on siiski ka oma piirangud: selles esinevad eelkõige prototüüpse agendi ja patsiendiga verbide nominalisatsioonid, st selliste verbide nominalisatsioonid, mille agent on inimene ja patsient loodud (effected) või mõjutatud (affected) objekt. 
Tabel 5

\begin{tabular}{|c|c|c|c|}
\hline \multicolumn{3}{|c|}{$\begin{array}{l}\text { passiivne inhoatiivne } \\
\text { allatiiv/illatiiv +minema }\end{array}$} & \multirow{2}{*}{\begin{tabular}{|l}
$\begin{array}{l}\text { Püsiühendid } \\
\text { kujul alla- } \\
\text { tiiv/illatiiv } \\
\text { +minema }\end{array}$ \\
kumul. \% \\
\end{tabular}} \\
\hline astak & kumul. \% & Näiteid & \\
\hline 1 & 15 & $\begin{array}{l}\text { jagamisele, erastamisele, vahetusse, } \\
\text { remonti minema }\end{array}$ & 62 \\
\hline 2 & 32 & $\begin{array}{l}\text { kinnitamisele, töötlemisele, } \\
\text { uuringutele minema }\end{array}$ & 68 \\
\hline 3 & 47 & $\begin{array}{l}\text { hääletamisele, kasutusse, tootmisesse, } \\
\text { hävitamisele minema }\end{array}$ & 71 \\
\hline 4 & 50 & $\begin{array}{l}\text { ladumisele, väikeseeriatootmisse } \\
\text { minema }\end{array}$ & 71 \\
\hline 5 & 59 & $\begin{array}{l}\text { taastäitmisele, ümbervaatamisele } \\
\text { minema }\end{array}$ & 74 \\
\hline 6 & 69 & $\begin{array}{l}\text { väljavahetamisele, hukkamisele } \\
\text { minema }\end{array}$ & 75 \\
\hline 7 & 73 & $\begin{array}{l}\text { ümberjagamisele, ülevaatamisele } \\
\text { minema }\end{array}$ & 76 \\
\hline 8 & 86 & $\begin{array}{l}\text { sulgemisele, avaldamisele, } \\
\text { täiendamisele, kapitaalremonti } \\
\text { minema }\end{array}$ & 76 \\
\hline 9 & 94 & $\begin{array}{l}\text { kõrvaldamisele, teostamisele, } \\
\text { kustutamisele minema }\end{array}$ & 100 \\
\hline 10 & 100 & $\begin{array}{l}\text { arutamisele, tarvitusele, } \\
\text { tagastamisele minema }\end{array}$ & 100 \\
\hline
\end{tabular}

Malli esindavad nii kinnistunud ka kui produktiivselt moodustatud ühendid. Kinnistunud ühendid sisaldavad enamasti lühemaid ebareeglipäraseid teonimesid ja neis esineb nii illatiiv kui ka allatiiv, samuti võib neil olla teatud määral leksikaliseerunud tähendus ${ }^{11}$. Produktiivselt moodustatud ühendid seevastu

${ }^{11}$ Sellele viitab näiteks see, et kui samast sõnast esinevad seda tüüpi väljendites erinevad vormid, võivad need väljendid tähenduselt erineda, nt müüki/müügile minema. Malli esindab ka mittekompositsioonilise tähendusega väljend töösse minema: väljendi sisuliseks tuumaks on intransitiivne nominalisatsioon, kuid väljend ise on passiivse tähendusega. 
sisaldavad rohkem reeglipäraseid mine-teonimesid allatiivis. Internetiotsinguga võib siiski leida ka selliseid mittekonventsionaalseid passiivseid algusväljendeid, mille tuumaks on ebareeglipärane teonimi või illatiivivorm (nt minema arendusse, asendusse, ehitusse, filmimisse, haudesse, hindamisse, hääletusse, jaotusse, kärpesse ..), ning vastupidi, allatiivis mineteonimega väljend võib olla kinnistunud ja leksikaliseerunud tähendusega (minema esimesele/teisele/kolmandale lugemisele).

Oma produktiivses osas meenutab mall mitmes mõttes abiverbikonstruktsiooni: on küllalt neutraalse aspektuaalse/temporaalse ja tegumoetähendusega; säilitab teonime alusverbi argumendid, mis võivad realiseeruda ka lause tasandil, st väljaspool nimisõnafraasi (nt Ettevõtete vahel läheb jagamisele 2,1 mld krooni); moodustab aspektuaalse opositsiooni progressiivse passiivse konstruktsiooniga, mis koosneb verbist olema ja adessiivis mine-teonimest (nt Maja on lammutamisel; lähemalt mõlemast konstruktsioonist vt Sahkai 2005), ning passiivi perfektiga (Maja on lammutatud).

Selle väljendite rühma puhul tekib küsimus, milline on kinnistunud väljendite ja produktiivse malli vahekord. Kas püsiühendid on produktiivse malli alusel moodustatud väljendid, mis on keeles kinnistunud? Või on produktiivne mall kasvanud välja püsiühenditest? Või on nad kujunenud paralleelselt? Malli algupära kohta võib oletada, et see pärineb „passiivsest“ otstarbekonstruktsioonist, kus eesmärgiks on tegevus, mida väljendab illatiivne või allatiivne tegevusnimisõna või infinitiiv, nt Auto viiakse/läheb (töökotta) remonti/värvimisele/värvida. Kui subjekti referent on „mobiilne“, võib sama väljend olla tõlgendatav nii otstarbe- kui ka alguse-/tuleviku-konstruktsioonina, vrd Laev läheb lammutamisele. Võimalik, et mall on tekkinud tüüpilise abiverbikonstruktsiooni tekkestsenaariumi järgi, kuid püsiühendite roll selles vajab eraldi uurimist.

Tekib küsimus, miks on see mall produktiivne, samal ajal kui küllalt sarnased nimisõnalise tuumaga aktiivsed väljendid ei ole moodustanud produktiivset malli? Kui oletasime, et aktiivse malli teket blokeerib ühe tegurina sünonüümsus üldisema $h a k$ kama-malliga, siis passiivsetele väljenditele otsest üldisemat sünonüümset väljendusvahendit ei leidu - lähim alternatiiv on 
impersonaal, mille semantika ja pragmaatika on passiivist siiski mõnevõrra erinev. Homonüümne otstarbemäärusemall aga ei blokeeri algusemalli ilmselt seetõttu, et on ise selle aluseks ning „liikuva“ subjekti korral on mõlemad tõlgendused sageli samaaegselt tõesed, „mitteliikuva“ subjekti puhul aga on ühemõtteliselt võimalik ainult algusetõlgendus.

\subsection{Impersonaalne konstruktsioon: läheb löömaks, läheb peoks jt}

Teise produktiivse mallina vaatleme impersonaalse tähendusega konstruktsiooni, mille tuumaks on translatiivne tegevusnimisõna (mallis esinevad nii mine-teonimed kui ka ebareeglipärasemad tuletised). Nagu ilmneb tabelitest 4 ja 6 , on see andmestiku produktiivseim konstruktsioon, kuid seda esindavad siiski ka mõned püsiühendid, nt löömaks, kakluseks, madinaks minema.

Mall on semantiliselt suhteliselt avatud, kuigi selles esinevad nimisõnad koonduvad ühe keskse rühma ümber, mis moodustab peaaegu kolmandiku kõigist mallis esinevatest sõnadest: selleks on füüsilist ja verbaalset konflikti väljendavad sõnad (kokku 34, nt kaklus, kisma, kokkupõrge, kähmlus, vaidlus, riid, tüli ..). Keskse rühmaga on erinevate tunnuste alusel seotud verbaalseid ja vokaalseid tegevusi väljendavad nimisõnad (12 sõna, nt arutelu, heietamine, jahumine, vadistamine) ning kollektiivseid (sageli mittekooperatiivseid, vrd Vainik ja Sahkai 2009) või interaktiivseid tegevusi väljendavad sõnad (24 sõna, nt sagimine, sebimine, trügimine, tants, pidu, võistlus). Kuid esines ka 27 sõna, mis otseselt keskse rühmaga ei seostu (nt ehitamine, kolimine, söömine, autoost, purustamine, uurimine). Malli produktiivsusest annab tunnistust seegi, et võimalikud on sünonüümsed väljendid regulaarse mine-tuletisega ja sellega enam-vähem sünonüümse nimisõnaga: mänguks/mängimiseks minema; kaklemiseks/kakluseks minema. Mall ei ole siiski täiesti avatud, vaid piiratud potentsiaalselt agentiivseid tegevusi väljendavate nimisõnadega. 
Tabel 6

\begin{tabular}{|c|c|c|c|}
\hline \multicolumn{3}{|c|}{$\begin{array}{l}\text { impersonaalne } \\
\text { minema+translatiiv }\end{array}$} & \multirow{2}{*}{\begin{tabular}{|l} 
püsiühendid \\
kujul \\
translatiiv \\
+ minema
\end{tabular}} \\
\hline astak & kumul. \% & näiteid & \\
\hline 1 & 20 & $\begin{array}{l}\text { kakluseks, sõjaks, löömaks, } \\
\text { verevalamiseks, peoks, jagamiseks, } \\
\text { madinaks minema }\end{array}$ & 60 \\
\hline 2 & 35 & $\begin{array}{l}\text { tellimiseks, tantsuks, lahinguks, } \\
\text { tüliks, ̈̈riks minema }\end{array}$ & 70 \\
\hline 3 & 44 & $\begin{array}{l}\text { kaklemiseks, keevitamiseks, } \\
\text { kohtuvaidluseks, kirjandusjutuks } \\
\text { minema }\end{array}$ & 80 \\
\hline 4 & 59 & $\begin{array}{l}\text { rüsinaks, sebimiseks, } \\
\text { pulmasõiduks, saiasöömiseks } \\
\text { minema }\end{array}$ & 80 \\
\hline 5 & 68 & $\begin{array}{l}\text { kriiskamiseks, maitsmiseks, } \\
\text { rohuvõtmiseks minema }\end{array}$ & 80 \\
\hline 6 & 79 & $\begin{array}{l}\text { vaidlemiseks, nõupidamiseks } \\
\text { minema }\end{array}$ & 90 \\
\hline 7 & 85 & kolimiseks, ehitamiseks minema & 90 \\
\hline 8 & 88 & $\begin{array}{l}\text { mänguks, võistluseks, ostuks } \\
\text { minema }\end{array}$ & 100 \\
\hline 9 & 96 & $\begin{array}{l}\text { moodustamiseks, koostööks } \\
\text { minema }\end{array}$ & 100 \\
\hline 10 & 100 & $\begin{array}{l}\text { liikumiseks, hindamiseks, tööks } \\
\text { minema }\end{array}$ & 100 \\
\hline
\end{tabular}

Mallis esinevate sõnade tähendusliku jaotuse põhjal võib oletada, et see on välja kasvanud semantiliselt ühtsest püsiühendite rühmast (mis omakorda võib olla tekkinud produktiivse seisundimuutusmalli [minema+ADJtransl] laiendusena, mida esindavad ka mõned nimisõnalise tuumaga väljendid, nt tormiks/sulaks minema).

Erinevalt eelkirjeldatud passiivsest konstruktsioonist ei meenuta see mall abiverbikonstruktsiooni: ta esineb küllalt erandlikus aluseta lausemallis, ei erine süntaktiliselt verbi-laiendi kombinatsioonist, kuigi nimisõna agentargument võib realisee- 
ruda lause tasandil adessiivargumendina (nt Seda ma arvasin, et teil jälle jorutamiseks läheb), ning on teatava raskesti kirjeldatava semantilise või pragmaatilise lisaväärtusega, mille võib võtta kokku mõistetega afektiivsus ja mitteformaalsus (Vainik ja Sahkai 2009).

Kui otsida produktiivsuse tegureid, siis ka seda malli võib motiveerida spetsiifiline tähendus(varjund) ja seega sünonüümse väljendusvahendi puudumine, samuti homonüümsete konstruktsioonide puudumine.

\section{Järeldused ja kokkuvõte}

Kokkuvõtteks võib öelda, et vaadeldud liitpredikaadid toetavad Barðdali (2008: 44) käsitlust produktiivsusest kui skaalast (cline, gradient), mille ühes otsas on analoogia ja teises täielik produktiivsus, ning pakuvad head ainestikku selle uurimiseks. Andmestikust ilmnesid järgmised produktiivsuse tüübid:

- üksikud kinnistunud ühendid või väikesed kinnistunud ühendite rühmad, mis ei ole siiski produktiivsuse seisukohast sugugi inertsed (nimisõnalise tuumaga aktiivsed ühendid, nt langusse minema);

- suurem kinnistunud ühendite rühm (keema, liikuma mine$m a$-tüüp), mis ilmutab mõningaid analoogilise laienemise märke ja annab mittekonventsionaalseid ühendeid, kuid ei ole moodustanud produktiivset malli, ehkki väljendid moodustavad semantiliselt ühtse rühma, millel oleks ka laienemisruumi;

- väga kitsa tähendusrühma piires produktiivne mall ( $k a k$ lema minema-tüüp);

- kaks semantiliselt avatud erineval määral produktiivset malli: esiteks abiverbikonstruktsiooni meenutav passiivne konstruktsioon (nt lammutamisele minema), teiseks idiosünkraatilise lausemalli ja spetsiifilise pragmaatilise varjundiga ,impersonaalne" konstruktsioon (nt löömaks minema), mis neist omadustest hoolimata on andmestiku produktiivseim; mallid tunduvad olevat ka erineva tekkelooga. Kumbki neist mallidest pole siiski täiesti produktiivne.

Erinevate produktiivsuse määrade ja tüüpide rohkus loob keelelise teadmise struktuurist küllalt amorfse ja fragmentaarse 
mulje. Seda muljet toetab eriti püsiühendite ja skemaatiliste mallide vaheline hajus üleminek ja nende põimunud vahekorrad: püsiühendid on alati mingi skemaatilise malli kinnistunud esindajad või laiendused, kuid võivad olla aluseks ka uutele väljenditele ja uute mallide tekkele; samuti tundub, et püsiühendid ja mallid võivad tekkida sarnaste või paralleelsete diakrooniliste protsesside tulemusena. See kõik loob uute keeleväljendite moodustamisest hoopis teistsuguse pildi kui teooria, mille kohaselt see seisneb sõnade kombineerimises leksikaalsete valikukitsenduste ja üldiste grammatiliste reeglite alusel: tundub, et selles mängivad suurt rolli ,salvestatud“ üksused ja suhteliselt piiratud mallid. Võib seega öelda, et liitpredikaadid toetavad kasutuspõhiseid ja leksikoni-grammatika kontiinuumi eeldavaid keelekäsitlusi ning pakuvad head ainestikku nende arendamiseks.

Analüüsi kokkuvõtteks võime tõdeda ka seda, et liitpredikaadid pakuvad häid võimalusi konstruktsioonide produktiivsuse tegurite ehk produktiivsusega korreleeruvate tunnuste uurimiseks, sest võimaldavad konstrueerida „minimaalpaare“ erineva produktiivsusega konstruktsioonidest, millel on suhteliselt palju ühiseid omadusi. Antud juhul olid ühisteks omadusteks ehk kontrollitud teguriteks finiitverb, tuumkomponendi latiivne vorm ja ühendi tähendus/funktsioon, millega produktiivsus seega ei korreleerunud. Produktiivsus ei korreleerunud ka tuumkomponendi sõnaliigiga ega sellega, kas selleks on reeglipärane või ebareeglipärane tuletis. Samuti ei korreleerunud produktiivsus sellega, kas konstruktsiooni tähendus/pragmaatika on spetsiifilisem või neutraalsem, ega ka mitte semantilise ühtsusega.

Küll aga korreleerus produktiivsus alternatiivse üldisema väljendusvahendi olemasoluga: aktiivsed väljendid (langusse minema-tüüp ja keema minema-tüüp) ei ole andnud produktiivset alguskonstruktsiooni, sest see oleks sünonüümne üldise hakkama-konstruktsiooniga. Samuti võib produktiivse malli teket takistada eksisteeriv homonüümne mall. Seega kui kirjanduses nimetatakse produktiivsuse teguritena enamasti konstruktsioonide endi omadusi (semantiline ühtsus, tüübisagedus), siis antud uurimusest ilmnesid olulisemana konstruktsioonivälised tegurid. 
Kadri Muischnek

Eesti ja üldkeeleteaduse instituut

Tartu Ülikool

Ülikooli 18, 50090 Tartu

Kadri.Muischnek@ut.ee

Heete Sahkai

Eesti Keele Instituut

Roosikrantsi 6, 10119 Tallinn

Heete.Sahkai@eki.ee

\section{Kirjandus}

Ackerman, Farrell, Gert Webelhuth (1998) A theory of predicates. Stanford,CA: CSLI Publications.

Alsina jt 1997 = Alsina, Alex, Joan Bresnan, Peter Sells, toim. (1997) Complex predicates. Stanford,CA: CSLI Publications.

Baayen, Harald R. (2009) "Corpus linguistics in morphology: Morphological productivity". A. Lüdeling ja M. Kytö, toim. Corpus linguistics. An international handbook. Vol 2, 899-919. Berlin, New York: Walter de Gruyter.

Barðdal, Jóhanna (2008) Productivity. Evidence from case and argument structure in Icelandic. Amsterdam, Philadelphia: John Benjamins Publishing Company.

Boas, Hans C. (2008) "Determining the structure of lexical entries and grammatical constructions in construction grammar". Annual Review of Cognitive Linguistics 6, 113-144.

Butt, Miriam (2003) "The light verb jungle". Harvard Working Papers in Linguistics 9, 1-49.

Bybee, Joan, David Eddington (2006) "A usage-based approach to Spanish verbs of 'becoming"'. Language 82, 2, 323-355.

EKG II = Erelt, Mati, Reet Kasik, Helle Metslang, Henno Rajandi, Kristiina Ross, Henn Saari, Kaja Tael, Silvi Vare. Eesti keele grammatika II. Süntaks. Lisa: kiri. Trükki toimetanud Mati Erelt (peatoimetajana), Tiiu Erelt, Henn Saari, Ülle Viks. Tallinn: Eesti Teaduste Akadeemia Keele ja Kirjanduse Instituut, 1993.

Erelt, Mati (toim) (2003) Estonian language. (Linguistica Uralica. Supplementary series / vol 1.) Tallinn: Estonian Academy Publishers. 
Fillmore, Charles J. (2006) "The articulation of lexicon and constructicon". Plenaarettekanne 4. rahvusvahelisel konstruktsioonigrammatika konverentsil Tokyo ülikoolis 1.-3.09.2006.

Fillmore, Charles J. (2008) "Border conflicts: FrameNet meets construction grammar”. E. Bernal, J. DeCesaris, toim. Proceedings of the XIII EURALEX International Congress (Barcelona, 15-19 July 2008), 49-68. Barcelona: IULA, Documenta Universitaria.

Goldberg, Adele E. (2006) Constructions at work: the nature of generalization in language. Oxford: Oxford University Press.

Jackendoff, Ray (2008) "Construction after construction and its theoretical challenges". Language 84, 1, 8-28.

Krikmann, Arvo (2004) „Sai hea obaduse vastu obadust“: löömist ja peksmist märkivad väljendid eesti keeles. Reetor 3. Tartu: Eesti Kirjandusmuuseum. Folkloristika osakond. Eesti Kultuuriloo ja Folkloristika Keskus.

Lüdeling, Anke (2001) On particle verbs and similar constructions in German. Dissertations in Linguistics. The University of Chicago Press.

Metslang, Helle (1994) „Eesti ja soome - futuurumita keeled?“ Keel ja Kirjandus 37, 9, 534-547; 10, 603-616.

Metslang, Helle (2002) „Iseseisev verb või abiverb“. Ettekanne TÜ süntaksiseminaril.

Metslang, Helle (2004) „Väljendverb predikaadina“. Ettekanne TÜ süntaksiseminaril.

Muischnek, Kadri (2006) Verbi ja noomeni püsiühendid eesti keeles. (Dissertationes Philologiae Estonicae Universitatis Tartuensis 17.) Tartu: Tartu Ülikooli Kirjastus.

Müller, Stefan (2002) Complex predicates: Verbal complexes, resultative constructions, and particle verbs in German. Stanford,CA: CSLI Publications.

Rätsep, Huno (1978) Eesti keele lihtlausete tüübid. (Eesti NSV Teaduste Akadeemia Emakeele Seltsi toimetised 12.) Tallinn: Valgus.

Sahkai, Heete (2005) „Teonimi perifrastilises verbivormis“. Keel ja Kirjandus 48, 10, 790-807.

Uiboaed, Kristel (2010) „Statistilised meetodid murdekorpuse ühendverbide tuvastamisel". Helle Metslang, Margit Langemets, MariaMaren Sepper, toim. Eesti Rakenduslingvistika Ühingu aastaraamat 6, 307-326. Tallinn: Eesti Keele Sihtasutus.

Vainik, Ene, Heete Sahkai (2009) „Läheb aruteluks. Afektiivsus dünaamilise malli produktiivsuse tegurina“. Ettekanne II soome-eesti kognitiivse keeleteaduse konverentsil Kiljaval 10.-12.12.2009. 
Kadri Muischnek and Heete Sahkai. Complex Predicates on the Lexicon-Grammar Continuum. The paper reports a corpus-based study of a group of Estonian complex predicates, concentrating on their productivity and its factors. Productivity is estimated on the basis of the measures proposed by Harald Baayen (2009), the semantic coherence of the constructions (Barðdal 2008), and, as a novel method, the collocational strength of the expressions. The constructions share a number of formal and semantic properties but are found to represent very different types and degrees of productivity. The factor of productivity that emerges from the study is the existence of a more general synonymous or homonymous construction, which seems to prevent the rise or the extension of a new pattern. More generally, it is argued that complex predicates provide useful data for the study of productivity and for the development of non-modular and usage-based theories of language and of the conception of the lexicon-grammar continuum.

Keywords: Estonian, complex predicates, constructions, productivity, corpus-based study, collocational strength, linguistic theory 